\title{
Characterization of a haemolysin from Mycobacterium tuberculosis with homology to a virulence factor of Serpulina hyodysenteriae
}

\author{
Brendan W. Wren, ${ }^{1}$ Richard A. Stabler, ${ }^{1}$ Satya S. Das, ${ }^{1}$ Philip D. Butcher, ${ }^{2}$ \\ Joseph A. Mangan, ${ }^{2}$ Jonathan D. Clarke, ${ }^{2}$ Nicola Casali, ${ }^{3}$ Tanya Parish ${ }^{3}$ \\ and Neil G. Stoker ${ }^{3}$
}

Author for correspondence: Neil G. Stoker. Tel: +44 171927 2425. Fax: +44 1716374314. e-mail: N.STOKER@LSHTM.AC.UK

\footnotetext{
1 Department of Medical Microbiology, St

Bartholomew's and the Royal London School of Medicine and Dentistry, West Smithfield, London EC1A 7BE, UK

2 Department of Medical Microbiology, St George's Hospital Medical School, Cranmer Terrace, London SW17 ORE, UK

3 Department of Infectious and Tropical Diseases, London School of Hygiene \& Tropical Medicine, Keppel Street, London WC1E 7HT, UK
}

\begin{abstract}
Scrutiny of sequence data from the Mycobacterium leprae genome sequencing project identified the presence of a gene encoding a 268-amino-acid polypeptide which is highly similar to a pore-forming haemolysin/cytotoxin virulence determinant, TlyA, from the swine pathogen Serpulina hyodysenteriae. Using degenerate oligonucleotide primers based on the TlyA sequences, the Mycobacterium tuberculosis homologue was amplified and this product was used to obtain the clone and sequence a $2.5 \mathrm{~kb}$ fragment containing the whole $M$. tuberculosis t/yA gene. t/yA encodes a 267-amino-acid protein with a predicted molecular mass of $28 \mathrm{kDa}$. TlyA homologues were identified by PCR in M. leprae, Mycobacterium avium and Mycobacterium bovis BCG, but appeared absent in Mycobacterium smegmatis, Mycobacterium vaccae, Mycobacterium kansasii, Mycobacterium chelonae and Mycobacterium phlei. The $M$. tuberculosis gene appeared to be the first gene in an operon containing at least two other genes. Introduction of the $M$. tuberculosis $t / y A$ gene into $M$. smegmatis using a mycobacterial shuttle expression plasmid converted non-haemolytic cells into those exhibiting significant haemolytic activity. Similarly, inducible haemolytic activity was observed in sonicated

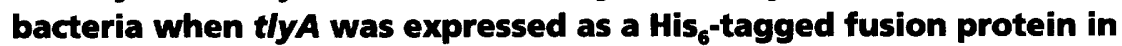
Escherichia coli. tlyA mRNA was detected in both $M$. tuberculosis and $M$. bovis BCG using RT-PCR, confirming that this gene is expressed in organisms cultured in vitro.
\end{abstract}

Keywords: Mycobacterium leprae, tlyA, recN, BCG, contact-dependent haemolysin

\section{INTRODUCTION}

The mycobacteria include major human pathogens, notably Mycobacterium tuberculosis and Mycobacterium leprae, the causative agents of tuberculosis and leprosy, respectively. Tuberculosis is the predominant infectious cause of morbidity and mortality worldwide, infecting 8 million and killing 3 million people annually (Snider et al., 1994). This situation is exacerbated by the HIV pandemic and the increased prevalence of multiply resistant M. tuberculosis (Smith \& Moss, 1994), while vaccine prophylaxis using Mycobacterium bovis BCG is unsatisfactory in many parts of the world

The GenBank/EMBL/DDBJ accession number for the sequence reported in this paper is $X 98295$.
(Rodrigues \& Smith, 1990). In addition, the Mycobacterium avium complex has emerged as a leading cause of infection in immunocompromised patients in developed countries (Porter, 1996). Despite a major research effort to characterize the pathophysiology of Mycobacterium species, few dedicated virulence determinants have been identified to date.

M. tuberculosis, M. leprae and M. avium are facultative intracellular organisms, having the capacity to survive in macrophages, and although the molecular basis of this property is not known, there have been reports suggesting that the bacteria are able to inhibit phagolysosome fusion (Armstrong \& Hart, 1971), exist within tight vacuoles (Moreira et al., 1997) and even escape into the cytoplasm (McDonough et al., 1993). Haemolytic activity, associated with cytoplasmic development, has 
been documented in a wide variety of viral, bacterial and protozoan pathogens, including Shigella, Rickettsia, Trypanosoma cruzi and Listeria monocytogenes (reviewed by Andrews \& Portnoy, 1994). Mutants of $L$. monocytogenes lacking the haemolysin listeriolysin $\mathrm{O}$ do not escape from the endosomal compartment and fail to become established in the cytoplasm. Furthermore, cloning the listeriolysin $\mathrm{O}$ gene into Bacillus subtilis produced a haemolytic organism which disrupted the phagolysosome membrane, permitting cytoplasmic growth. Thus a single gene product was sufficient to convert a common soil organism into an in vitro intracellular parasite (Bielecki et al., 1990).

There have been a number of reports of haemolytic activity in M. tuberculosis. King et al. (1993) detected a contact-dependent haemolysin activity in strain H37Rv which was much reduced in the avirulent derivative $\mathrm{H} 37 \mathrm{Ra}$, and not present in BCG. Two genes encoding phospholipase $\mathrm{C}$ enzymes, which have haemolytic properties, have been cloned (Johansen et al., 1996; Leao et al., 1995). Recently Deshpande et al. (1997) purified a $66 \mathrm{kDa}$ haemolysin from M. tuberculosis which showed limited homology to the haemolysin A precursor of Vibrio cholerae. It has also been shown that Mycobacterium haemophilum, which causes disease, most frequently in immunocompromised people, has a contact-dependent haemolysin (Fischer et al., 1996). These haemolysins are all contact-dependent, while there has been a report of a heat-stable extracellular haemolytic activity in fast-growing mycobacteria (Udou, 1994).

Using data from the $M$. leprae genome sequencing project (Genome Therapeutics Corporation, Waltham, USA), we identified the presence of a 268 -amino-acid polypeptide which shows striking similarity $(40 \%$ identity) to a haemolysin/cytotoxin, TlyA, from the spirochaete Serpulina byodysenteriae. The $S$. byodysenteriae protein is a $26.9 \mathrm{kDa}$ protein and is a major factor in the pathogenesis of swine dysentery (Hyatt et al., 1994; ter Huurne et al., 1994). In this paper, we describe the sequencing and initial characterization of the $M$. $t u$ berculosis tlyA gene and its product.

\section{METHODS}

Bacterial strains, plasmids and growth conditions. The bacterial strains and plasmids used in this study are listed in Table 1. Most mycobacterial strains were cultured in Middlebrook growth medium, except Mycobacterium smegmatis $\mathrm{mc}^{2} 155$, which was grown in Lemco or modified Dubos medium (Difco), at $37^{\circ} \mathrm{C}$ with the addition of $25 \mu \mathrm{g}$ kanamycin $\mathrm{ml}^{-1}$ or $100 \mu \mathrm{g}$ hygromycin $\mathrm{ml}^{-1}$ for strains containing plasmids. M. leprae DNA was provided by Dr M. J. Colston, National Institute for Medical Research, UK. Escherichia coli strains were routinely grown in LB broth or on LB agar. The antibiotics used for selection purposes were ampicillin $\left(100 \mu \mathrm{g} \mathrm{ml}^{-1}\right)$, kanamycin $\left(50 \mu \mathrm{g} \mathrm{ml}^{-1}\right)$ and hygromycin (50 $\left.\mu \mathrm{g} \mathrm{ml}^{-1}\right)$.

DNA manipulations and PCR. Plasmid and genomic DNA extractions, restriction enzyme digests, DNA ligations, and transformations into $E$. coli were performed by standard procedures (Sambrook et al., 1989) using enzymes supplied by Promega. Mycobacterial DNA was isolated by the method of Santos et al. (1992). Hybridization probes were labelled with digoxigenin-11-dUTP (Boehringer Mannheim) during PCR, and hybridization and detection were performed according to the manufacturer's instructions. The $M$. tuberculosis tly $A$ gene fragment was amplified by PCR with degenerate oligonucleotide primers using a method modified from that described by Wren et al. (1992). The oligonucleotides (CGCTGCAGCNWSSACNGGNTTYAC and CCAAGCTTCNRCYTCRAAYTGNGGYTT) were based on $M$. leprae and $S$. byodysenteriae sequence data and were designed to incorporate PstI and HindIII restriction endonuclease sites (underlined) into the amplified product. Mycobacterial chromosomal DNA (100 ng) was added to the PCR reaction mixture and submitted to 40 cycles of $1 \mathrm{~min}$ denaturation at $94^{\circ} \mathrm{C}, 1 \mathrm{~min}$ annealing at $40^{\circ} \mathrm{C}$ and $2 \mathrm{~min}$ extension at $72^{\circ} \mathrm{C}$ in a Hybaid Omnigene thermal cycler. The amplified product of predicted size was digested with $H$ indIII and $P s t \mathrm{I}$, ligated into similarly digested pUC18 to form pCIG7, and transformed into $E$. coli XL2-Blue MRF $^{\prime}$ cells (Stratagene). All DNA sequences were determined using an $\mathrm{ABI}$ PRISM Dye Terminator Cycle Sequencing kit (Perkin Elmer). The SmaI fragment containing the $t l y A$ gene was sequenced on both strands using primer walking.

Cosmid library screening. A cosmid library of M. tuberculosis H37Rv DNA in pYUB328 (provided by W. R. Jacobs, Albert Einstein College of Medicine, NY, USA) was used for screening. The cosmid library phage lysate was transduced into E. coli NM554 by the method of Eiglmeier et al. (1993). Colonies were picked onto gridded nylon membranes (Amersham), replicated, and membranes for screening were treated to lyse the colonies and immobilize the DNA according to Sambrook et al. (1989). A probe was generated from pCIG7 using the degenerate primers described above, and used for hybridization. Positive colonies were identified, picked from duplicate filters, grown, and cosmid DNA was isolated using the Wizard Minipreps DNA Purification System (Promega). Cosmid DNA was analysed by Southern blotting to confirm positive hybridization to the digoxigenin-labelled probe.

RT-PCR. Total RNA from M. bovis BCG and M. tuberculosis $\mathrm{H} 37 \mathrm{Rv}$ was isolated from mid-exponential-phase cultures using the method of Mangan et al. (1997) with primers $\mathrm{P}_{\mathrm{K} 1}\left\langle 5^{\prime}\right.$ GATCCTCGGGTGGTGGTC; nt 1026-1043 in the published sequence) and $\mathrm{P}_{\mathrm{K} 2}$ (5'-CCTCAAACTGGGGCTTCA$\mathrm{CC}$; nt 1212-1193), which were designed to give a $187 \mathrm{bp}$ product. Total RNA was treated with 1 unit RNase-free DNase I (Life Technologies) in $1 \times$ reaction buffer $(20 \mathrm{mM}$ Tris/ $\mathrm{HCl}, \mathrm{pH} 8.4,2 \mathrm{mM} \mathrm{MgCl}, 50 \mathrm{mM} \mathrm{KCl}$ ) for $15 \mathrm{~min}$ at room temperature. After digestion, the DNase I was inactivated by the addition of EDTA to $2 \mathrm{mM}$ followed by incubation at $65^{\circ} \mathrm{C}$ for $10 \mathrm{~min}$. The RNA was heat-denatured at $85^{\circ} \mathrm{C}$ for $5 \mathrm{~min}$ and quenched on ice prior to adding reverse transcriptase. The RNA was reverse-transcribed in a final volume of $20 \mu \mathrm{l}$ containing $2.5 \mu \mathrm{M} \mathrm{P}_{\mathrm{K} 2}, 40$ units RNasin (ribonuclease inhibitor), $1 \mathrm{mM}$ each dATP, dCTP, dGTP and dTTP, $5 \mathrm{mM}$ DTT and 200 units Superscript II reverse transcriptase (Life Technologies) in a reaction buffer consisting of: $50 \mathrm{mM}$ Tris/ $\mathrm{HCl}, \mathrm{pH} 8.3,75 \mathrm{mM} \mathrm{KCl}, 3 \mathrm{mM}$ $\mathrm{MgCl}_{2}$. Ten microlitres of heat-denatured RNA was added to $10 \mu \mathrm{l}$ of above mix and incubated at $42{ }^{\circ} \mathrm{C}$ for $30 \mathrm{~min}$. One microlitre of the reverse transcription mix was used for hot start PCR and added to $9 \mu \mathrm{l}$ water and $40 \mu \mathrm{l}$ PCR master mix. The master mix for one reaction contained $1 \mu$ primer $\mathrm{P}_{\mathrm{K} 1}$ $(50 \mu \mathrm{M}), 1 \mu \mathrm{l}$ primer $\mathrm{P}_{\mathrm{K} 2}(50 \mu \mathrm{M}), 5 \mu \mathrm{l} 10 \times \mathrm{Taq}$ polymerase reaction buffer $(100 \mathrm{mM}$ Tris $/ \mathrm{HCl}, \mathrm{pH} 9.0,500 \mathrm{mM} \mathrm{KCl}$, 
Table 1. Bacterial strains and plasmids

\begin{tabular}{|c|c|c|}
\hline Strain/plasmid & Relevant characteristics & Source/reference* \\
\hline \multicolumn{3}{|l|}{ Strains } \\
\hline \multicolumn{3}{|l|}{ E. coli } \\
\hline XL2-Blue MRF' & Cloning strain & Stratagene \\
\hline BL21 & Cloning strain & \\
\hline JM109 & Cloning strain & Stratagene \\
\hline NM554 & Cosmid host & Stratagene \\
\hline M. smegmatis $\mathrm{mc}^{2} 155$ & & Snapper et al. (1990) \\
\hline M. phlei NCTC 8156 & & Graham McIntyre \\
\hline M. chelonae ATCC 1977 & & Graham McIntyre \\
\hline M. vaccae clinical isolate & & Graham McIntyre \\
\hline M. kansasii USA patient & & Graham McIntyre \\
\hline M. avium NCTC 8559 & & Graham McIntyre \\
\hline M. bovis BCG Pasteur & & Graham McIntyre \\
\hline M. tuberculosis $\mathrm{H} 37 \mathrm{Rv}$ & & Graham McIntyre \\
\hline \multicolumn{3}{|l|}{ Plasmids } \\
\hline pUC18 & $\mathrm{Amp}^{\mathrm{R}}$ cloning vector & Pharmacia \\
\hline pCIG7 & Amp $^{\mathrm{R}}$ plus 303 bp M. tuberculosis tlyA gene fragment & This study \\
\hline pCIG19 & $\begin{array}{l}\text { pUC18 plus } 2 \cdot 5 \mathrm{~kb} M . \text { tuberculosis Smal fragment carrying tly } A \text { and } \\
\text { flanking DNA }\end{array}$ & This study \\
\hline c418 & Cosmid clone containing $t l y A$ & This study \\
\hline pSMT3 & $\mathrm{Hyg}^{\mathrm{R}}$, mycobacterial shuttle vector & Paedar O'Gaora \\
\hline pRSETC & $A m p^{R}$, expression plasmid & Invitrogen \\
\hline pRAS3.2 & pRSETC plus 1199 bp tlyA ORF & This study \\
\hline pDORF & pSMT3 plus $2.5 \mathrm{~kb} S m a \mathrm{I}$ fragment carrying $t l y A$ and flanking DNA & This study \\
\hline pTAg & $\mathrm{Amp}^{\mathrm{R}} \mathrm{Kan}^{\mathrm{R}}$, PCR cloning & Novagene \\
\hline
\end{tabular}

*Graham McIntyre, UCL Medical School, London; Paedar O'Gaora, Imperial College School of Medicine at St Mary's, London.

$15 \mathrm{mM} \quad \mathrm{MgCl}_{2}, 1 \%$ Triton X-100), $8 \mu \mathrm{l}$ dNTPs (each $1 \cdot 25 \mathrm{mM}), 25 \mu \mathrm{l}$ RNase-free water and $0.2 \mu \mathrm{l}$ Taq polymerase (Promega). PCR was performed for 40 cycles at $94^{\circ} \mathrm{C}$ for $1 \mathrm{~min}, 60^{\circ} \mathrm{C}$ for $2 \mathrm{~min}$ and $72{ }^{\circ} \mathrm{C}$ for $3 \mathrm{~min}$ followed by $10 \mathrm{~min}$ at $72^{\circ} \mathrm{C}$. PCR products were analysed directly on agarose gels.

Sequence data analysis. Amino acid homology searches were performed using BLAST (Altschul et al., 1990). DNA sequence analysis was performed using GeneJockey software (BioSoft) and amino acid sequences were aligned using CLUSTAL w (Thompson et al., 1994).

Protein expression studies. A $1332 \mathrm{bp}$ sequence containing the complete tly $A$ gene, $124 \mathrm{bp}$ of upstream sequence and $401 \mathrm{bp}$ of downstream sequence was amplified using primers C9P3RE3 (GACCCCGCCGACGCCGAGAAC) and C9P3RE2 (CCGGTAATCCTGTGCGACAAC) and cloned into the $\mathrm{pTAg}$ vector. A Bam HI-PstI fragment containing the 1332 bp sequence was directionally cloned in-frame into the pRSETC vector, making pRAS3.2. These clones were used to express the $M$. tuberculosis tlyA according to manufacturer's instructions. Samples were grown until the $\mathrm{OD}_{600}$ was 0.3 (Pharmacia LKB Ultrospec III spectrophotometer) and expression was induced with IPTG $(1 \mathrm{mM})$. Samples $(1 \mathrm{ml})$ were taken at hourly intervals between 0 and $4 \mathrm{~h}$. Lysed samples $(30 \mu \mathrm{g})$ were electrophoresed through a $12 \%$ SDS-polyacrylamide gel and stained with Coomassie blue.

Haemolysis assay. Contact-dependent haemolysin assays on intact cells were performed essentially as described by King et al. (1993). M. smegmatis transformants were grown up for $2 \mathrm{~d}$ in liquid medium plus hygromycin and frozen down. Frozen stocks were then diluted into liquid medium containing hygromycin and grown for $24 \mathrm{~h}$, to an $\mathrm{OD}_{600}>1 \cdot 0$. E coli strains were inoculated into broth and grown at $37^{\circ} \mathrm{C}$ for $24 \mathrm{~h} ; 3 \times 10^{10}$ bacteria were pipetted into $50 \mathrm{ml}$ plastic tubes, centrifuged, washed and resuspended at $10^{10}$ bacteria $\mathrm{ml}^{-1}$ in PBS, and $3 \times 10^{9}$ sheep erythrocytes were added. A final centrifugation ensured close contact between bacteria and red blood cells. The assays were incubated at $37^{\circ} \mathrm{C}$ for $24 \mathrm{~h}$ with $1 \mathrm{ml}$ samples removed after 4 and $24 \mathrm{~h}$ intervals. For bacterial cell lysates, cultures were sonicated on ice, centrifuged at $13000 \mathrm{~g}$ and sterilized using a $0.45 \mu \mathrm{m}$ filter. Samples $(200 \mu \mathrm{l})$ were added to $800 \mu \mathrm{l}$ of washed sheep erythrocytes and incubated at $37^{\circ} \mathrm{C}$ for $16 \mathrm{~h}$. Haemolytic activity was assayed by haemoglobin release and measured spectrophotometrically at $A_{545}$.

\section{RESULTS}

\section{Identification of mycobacterial homologues of $S$. hyodysenteriae TlyA}

Analysis of $M$. leprae cosmid L247 (U00021) revealed an ORF with a predicted amino acid sequence showing $34 \%$ identity to the $S$. hyodysenteriae TlyA. To investigate the prevalence of this gene in other mycobacterial species, degenerate oligonucleotide primers were designed to regions conserved between $M$. leprae and $S$. byodysenteriae TlyA proteins. These primers suc- 




Fig. 1. Southern analysis of mycobacterial tlyA genes. Genomic (lanes 1-4), cosmid (lanes 5-8) or plasmid (lane 9) DNA was digested with Smal followed by Southern analysis using a digoxigenin-labelled $M$. tuberculosis tlyA PCR product as probe. Lanes: 1, E. coli; 2, M. tuberculosis; 3, M. bovis BCG; 4, M. smegmatis; 5, c317; 6, c4H8; 7, c2D4; 8, c418; 9, pCIG7.

cessfully amplified a product of the predicted size (303 bp) from M. tuberculosis, M. leprae, M. bovis BCG and $M$. avium DNA, but no products were amplified with $M$. smegmatis, Mycobacterium vaccae, Mycobacterium kansasii, Mycobacterium chelonae or Mycobacterium phlei DNA, even when the annealing temperature was lowered to $35^{\circ} \mathrm{C}$ (data not shown).

\section{Cloning of the $\boldsymbol{M}$. tuberculosis homologue}

The 303 bp amplified product from M. tuberculosis was cloned into pUC18 producing pCIG7 and was sequenced. Sequence analysis showed the insert DNA to be highly similar, but not identical to, the $M$. leprae gene. The M. tuberculosis gene fragment was then used as a probe in a Southern hybridization experiment using SmaI-digested DNA. A single strong band of $2.5 \mathrm{~kb}$ was observed with both $M$. tuberculosis and BCG, but no band was seen with M. smegmatis (Fig. 1, lanes 2-4). An M. tuberculosis cosmid library was screened for the presence of $t l y A$, and four positive clones were identified. Cosmid DNA prepared from these clones was digested with SmaI and analysed by Southern blotting. A $2.5 \mathrm{~kb} \mathrm{SmaI}$ fragment identified in all four cosmids, with a mobility identical to that found with genomic DNA (Fig. 1, lanes 5-8), was subcloned from cosmid c4I8 into pUC18, producing the plasmid pCIG19.

\section{Sequencing of t/yA}

The entire pCIG19 insert was sequenced and a complete ORF encoding the TlyA homologue was identified. A database search using BLAST showed the predicted TlyA protein sequence was similar to hypothetical proteins from B. subtilis ( $41 \%$ identity), Synechocystis sp. strain PCC 6803 (45\% identity) and Helicobacter pylori (43\% identity) in addition to those from $S$. byodysenteriae ( $40 \%$ identity) and $M$. leprae $(78 \%$ identity). The deduced amino acid sequences are shown aligned in Fig. 2. We believe that the GTG at position 654 of the $M$. tuberculosis Smal fragment is likely to be the start

\begin{tabular}{|c|c|}
\hline & \\
\hline thub & R--RARVDAELVRRGLARSRQQAAELIGAGKVRIDGLPAVKPATAVSDTTALTVVTDSERA \\
\hline p & R--RVRVDVELVRRGLARSRQQAAKLISAGKVS IDGLPAVKPSTAVAITTVLTVADDGE \\
\hline hyo & LDEYVHSEGYTBSRSKAQDI ILAGCVFVNGVKVTSKAHKIKDTDNIBVVQN - - \\
\hline sp & AKADKQRLDALLVAKGLCESRALAQRLIRAGEVKVNQQLVDKPGTLVTMDVAVELAQRPP - - YVSRGGEKLAKAL'] \\
\hline st & SKKERLDVLLVERGLAETREKAKRAIMAGIVYSNENRLDKPGEKIDRDLPLTVKGNP-II \\
\hline & $|=||||| * *|||*|=|| *|| *||$ \\
\hline 1.tub & VLLDRGAAHVVAADVGYGQLAWSLRNDPRVVVLERTNAR-GLTPEATGGR - - VDLVVADLSF \\
\hline p & LLDRGAAEVVAVDVGYGQLANSVRCDPRVIVVERTVVH-DLSPELIGGP- - -VDLVVA \\
\hline S.hyo & CLLKHGAKKVYALDVGENQLVYKLRNDNRVVS IEDFNAK-DINKEMFNDE- - IPSVIVSDVSFIS ITKIAPIIFKELN \\
\hline$p$ & LLQRGATKVYGVDVGYGQVAWKLRQDDRVILRERANFR - YLTPQDLYGDQPWPDLGVMDLSF ISLTKVMAPLWSLL \\
\hline B.sub & ALQNGAKQSYAVDVGYNQLAWKLRQDERVVVMERTNFR-YATPADFTKG- -MPEFATIDV \\
\hline H.pyl & 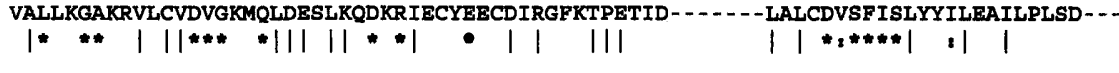 \\
\hline & 201 \\
\hline thub & AQELGWHSV \\
\hline & GGVVRDLRLRADSVLAVARRATELGWRTMDVTASSLPGLSC \\
\hline S.hyo & KGGIIRDDILREKILNNAISKIIDCGFKBVNRTISPIKGAKGNIEYLAHFII \\
\hline Syn.sp & KKGVVRDAQAQAEAIDQVWRSGQSLGWQFNGLTFSPITGPAGNVEYLLWLS-QSAV \\
\hline & GKGIVRDPKVHADVLKRMISFSAAEGY ICKGLSFSP \\
\hline H.pyl & 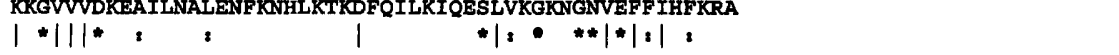 \\
\hline
\end{tabular}

Fig. 2. Comparison of the deduced TlyA amino acid sequences. The deduced amino acid sequences of TlyA homologues from $M$. tuberculosis (M. tub), M. leprae (M. lep) (Z95117), S. hyodysenteriae (S. hyo) (Q06803; Muir et al., 1992$), B$. subtilis (B. sub) (P19672), H. pylori (H. pyl) (AE000615) and Synechocystis sp. strain PCC 6803 (Syn. sp) (D90914) were aligned as described in Methods. An asterisk indicates that the amino acids are identical in all six sequences, a vertical line indicates that they are identical in four of the sequences, and a colon indicates that although fewer than four sequences are identical, there are conserved amino acids in all six sequences. 


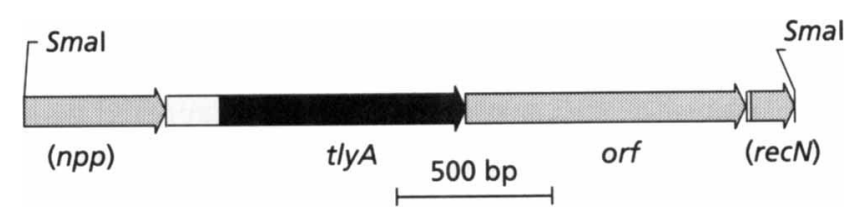

Fig. 3. tlyA gene organization. The gene organization of the $2.5 \mathrm{~kb}$ Smal fragment is shown. The tlyA gene is shown in black, and other ORFs are cross-hatched. Putative non-coding regions are shown in white. npp, end of gene encoding putative nitrophenylphosphatase; orf, ORF with homology only to genes of unknown function; recN, start of gene encoding putative RecN protein.

Table 2. Detection of tlyA-encoded haemolytic activity

\begin{tabular}{|lrl|}
\hline Strain & $n$ & \multicolumn{1}{c|}{$\begin{array}{c}\text { Contact } \\
\text { haemolytic } \\
\text { activity } \pm \text { SE }^{*}\end{array}$} \\
\hline M. smegmatis/pSMT3 & 10 & $0.498 \pm 0.025$ \\
M. smegmatis/pDORF & 5 & $0.739 \pm 0 \cdot 103 \dagger$ \\
E. coli JM109 & 3 & $0 \cdot 226 \pm 0.015$ \\
E. coli JM109/pRSETC & 3 & $0 \cdot 248 \pm 0.018$ \\
E. coli JM109/pRAS3.2 & 3 & $0.913 \pm 0.031 \ddagger$ \\
\hline
\end{tabular}

${ }^{*}$ Read after $24 \mathrm{~h}$ incubation.

$\dagger P$ value (unpaired two-tailed $t$-test) was $<0.01$.

$\ddagger P$ value (unpaired two-tailed $t$-test) was $<0.0001$ for pRAS3.2 compared to pRSETC.

codon, yielding a 267 -amino-acid polypeptide with a predicted molecular mass of $28 \mathrm{kDa}$. There was one other GTG in the tlyA ORF at position 495, but we think it is unlikely to be relevant because the $M$. leprae TlyA protein shows high similarity only from the start codon equivalent to $\mathrm{GTG}_{654}$, and this is the first possible start in that ORF. The sequence just upstream of the $M$. tuberculosis GTG $_{654}$ is AGGGTTGAGTG(N) ${ }_{4}$, which contains some matches with $M$. tuberculosis $16 \mathrm{~S}$ rRNA, and may therefore function as a ribosome-binding site.

ORFs were found on both sides of the tly $A$ gene. There is the end of an ORF $181 \mathrm{bp}$ upstream of the putative start $\mathrm{GTG}_{654}$ of $t l y A$; this ORF encodes a protein showing similarity to $p$-nitrophenylphosphatase of Schizosaccharomyces pombe (Yang et al., 1991). Another ORF starts at the 3 '-end of tlyA, with a GTG overlapping the tly $A$ stop codon; the encoded protein is $32.9 \mathrm{kDa}$, and homology searches pick up good matches with hypothetical proteins from other genomes, but none of known function. Just downstream of this gene is the start of a gene encoding a protein which shows homology to $E$. coli $\mathrm{RecN}$; the gap between stop and start codons is just $14 \mathrm{bp}$, again suggesting that they are part of the same transcriptional unit. Thus tlyA appears to be the first gene in an operon containing at least three genes (see Fig. 3). The TlyA protein does not have a classical $\mathrm{N}$-terminal signal sequence.

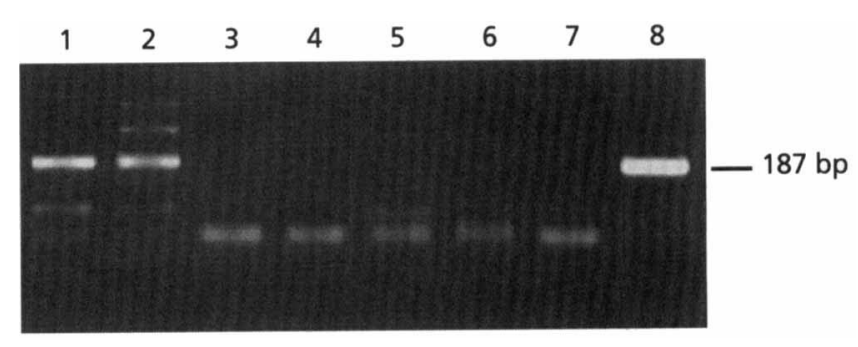

Fig. 4. RT-PCR analysis of tlyA expression. DNase-treated total RNA was extracted from in mid-exponential-phase growth from $M$. bovis BCG and $M$. tuberculosis H37Rv, and tlyA-specific RTPCR was carried out. Lanes: 1, $M$. tuberculosis H37Rv; $2, M$. bovis BCG; 3, $M$. tuberculosis H37Rv PCR without RT; 4, $M$. bovis BCG PCR without RT; $5, M$. tuberculosis H37Rv RT-PCR following RNase A treatment; $6, M$. bovis BCG RT-PCR following RNase A treatment; 7, RT-PCR negative control lacking nucleic acid; 8, M. bovis BCG PCR using genomic DNA (100 ng).

\section{Expression of TlyA and haemolysis assays}

We wished to determine whether M. tuberculosis TlyA possesses haemolytic activity, as has been shown with the $S$. hyodysenteriae protein. We therefore cloned the $2.5 \mathrm{~kb}$ SmaI fragment containing tly $A$ into the mycobacterial expression plasmid pSMT3, downstream of the strong BCG $h s p 60$ promoter, which is highly active even without heat shock (Stover et al., 1991), producing pDORF, which was introduced into $M$. smegmatis $\mathrm{mc}^{2} 155$. Other investigators have observed that recombinant protein expression may vary among mycobacterial transformants carrying the same plasmid (D. Young, personal communication), so five separate colonies were picked and contact-dependent haemolysin activity was assayed. We did indeed find variable expression, but the results shown in Table 2 demonstrate that colonies carrying pDORF were significantly more haemolytic than those carrying the vector alone $(P<0 \cdot 01)$.

To obtain further evidence of the activity of $M$. tuberculosis TlyA, a 1332 bp PCR fragment containing the complete tlyA gene was cloned into pRSETC and expressed in E. coli JM109 as a fusion protein with a short $\mathrm{N}$-terminal $\mathrm{His}_{6}$ tag. We also included $125 \mathrm{bp}$ of sequence upstream of what we now believe to be the start codon, because at the time we were unsure where translation began. This plasmid, pRAS3.2, was sequenced to confirm that the complete tly $A$ gene had been cloned, and was in the correct reading frame for expression. SDS-PAGE analysis on sample preparations of $E$. coli/pRAS3.2 revealed a product of the predicted size (not shown). Cell extracts of E. coli/pRAS3.2 exhibited significant haemolytic activity when induced by IPTG compared to control extracts (Table 2).

\section{Analysis of tlyA transcription}

To determine if tlyA is actively transcribed, specific mRNA was measured from mid-exponential-phase cultures of $M$. tuberculosis and M. bovis BCG using RTPCR. A band of the correct size (187 bp) was detected 
with both species, indicating the presence of tly mRNA (Fig. 4, lanes 1 and 2). Controls showed that the bands were produced by mycobacterial RNA and not genomic DNA (lanes 3-6).

\section{DISCUSSION}

We have identified an M. tuberculosis 268-amino-acid polypeptide which shows high homology to the TlyA haemolysin/cytotoxin from the spirochaete $S$. byodysenteriae. We have demonstrated that the $M$. tuberculosis TlyA exhibits contact-dependent haemolytic activity when introduced into a non-haemolytic $M$. smegmatis strain, and when cloned into $E$. coli as a fusion protein. We have also shown that the tly $A$ gene is expressed in both $M$. tuberculosis and M. bovis BCG.

$S$. hyodysenteriae is the aetiologic agent of swine dysentery, an infection characterized by a mucohaemorrhagic diarrhoea. Three genes encoding haemolysins have been found $(t l y A, B$ and $C)$. Several lines of evidence suggest that in $S$. byodysenteriae haemolysin activity is a major virulence determinant. These are that (1) purified TlyA is haemolytic and cytotoxic for a number of cell types (ter Huurne et al., 1994), (2) the gene is absent in naturally occurring non-pathogenic strains, such as Serpulina innocens (Muir et al., 1992), and (3) defined tly $A$ mutants from two independent strains were less virulent in both mice (ter Huurne et al., 1994) and pigs (Hyatt et al., 1994). There is evidence that the haemolytic activity of TlyA is due to pore formation, rather than through proteolytic or enzymic activity (Hyatt \& Joens, 1997).

The distribution of the gene among bacterial species is interesting, in that while it is found in some pathogens (S. byodysenteriae, H. pylori), homologues are also present in non-pathogens (B. subtilis, Synechocystis sp.), and other bacteria have no homologue (Haemopbilus influenzae, Methanococcus jannaschii and E. coli). While we cannot predict the role of this protein in these different species, we have shown that whatever its function, the $M$. tuberculosis gene is expressed, and the protein possesses haemolytic activity. Furthermore, our preliminary evidence suggests that this gene is restricted to pathogenic species within the mycobacteria. It will be necessary to compare a virulent strain of $M$. tuberculosis with a tlyA mutant to prove or disprove a role in virulence.

Analysis of the sequenced region raises a number of questions. Firstly, it appears that $t l y A$ is the first gene in an operon in both $M$. tuberculosis and M. leprae. The roles of the other genes are not clear; one only shows homology to ORFs with unknown function in other bacteria, while the third shows homology to $E$. coli $r e c N$. As yet, we have no rationale for the role played by these genes. Secondly, if TlyA functions as a haemolysin in vivo, one would expect it to be extracytoplasmic. The protein does not contain a classical N-terminal signal sequence, so we do not know how the protein passes through the cytoplasmic membrane. However, the same is true for the $S$. byodysenteriae protein, which is secreted from the treponeme, and is exported to the periplasm of $E$. coli, suggesting that it is exported by a different route.

There is as yet no direct evidence that haemolysins are important virulence factors in mycobacterial infections, but several proteins with haemolytic activity have been reported (see Introduction). Such proteins might alter the membrane encompassing the bacteria in macrophage phagosomes, allowing the bacteria to interfere with the host cells' killing mechanisms. Even if the bacteria remain within a phagosomal membrane, as appears to be the norm (see review by Clemens, 1996), a haemolysin may alter the properties of the membrane to allow molecules to pass through more readily. The presence of bacterial proteins in the cell cytoplasm might explain the evidence that the major histocompatibility complex class I pathway of antigen presentation is important in the immune response to $M$. tuberculosis. For example, CD8 cytotoxic T cell responses to live BCG have been reported (Turner \& Dockrell, 1996), and mice lacking a functional $\beta_{2}$ microglobulin gene are more susceptible to M. tuberculosis than M. bovis BCG (Flynn et al., 1992). These results suggest that class I presentation is important in both $M$. tuberculosis and $M$. bovis BCG, but more so in the former. This may correlate with the detection of greater haemolysin activity in $M$. tuberculosis (King et al., 1993). Our results show that tlyA is present and expressed in $M$. bovis BCG. Thus either TlyA is not the major haemolysin detected by King $e t$ al. (1993), or its expression differs in the two organisms. Our RT-PCR results were not quantitative, so we do not know the relative levels of expression; also, our experiments used organisms cultured in vitro, and expression may differ in vivo.

The tlyA mutant of $S$. hyodysenteriae offered partial protection against challenge with the wild-type strain (Hyatt et al., 1994; ter Huurne et al., 1994), and if we can demonstrate attenuation of an equivalent mutant of $M$. tuberculosis, inactivation of the gene may be desirable in a rational vaccine strain. Alternatively, if haemolytic activity is important for production of a CD8 cytotoxic reponse, it may be better to retain this function, and concentrate on attenuation of other pathways.

\section{ACKNOWLEDGEMENTS}

We would like to thank Doug Smith for sharing his M. leprae sequence analysis at an early stage, Claire Bury and Heidi Robinson for technical assistance, Bill Jacobs for the $M$. tuberculosis pYUB328 library, Paedar O'Gaora for pSMT3, Graham McIntyre for mycobacterial strains and Jo Colston for M. leprae DNA. We are also grateful to Ian White for advice on statistical analyses and Hazel Dockrell for helpful discussions. R.A.S. was funded by the St Bartholomew's Joint Research Board, N.C. by a Medical Research Council studentship and T.P. by Wellcome Trust grant $0366088 / Z$.

\section{REFERENCES}

Altschul, S. F., Gish, W., Miller, W., Myers, E. W. \& Lipman, D. J. (1990). Basic local alignment search tool. J Mol Biol 215, 403-410. 
Andrews, N. W. \& Portnoy, D. A. (1994). Cytolysins from intracellular pathogens. Trends Microbiol 2, 261-263.

Armstrong, J. A. \& Hart, P. D. (1971). Response of cultured macrophages to Mycobacterium tuberculosis, with observations on fusion of lysosomes with phagosomes. J Exp Med 134, 713-740.

Bielecki, J., Youngman, P., Connelly, P. \& Portnoy, D. A. (1990). Bacillus subtilis expressing a haemolysin gene from Listeria monocytogenes can grow in mammalian cells. Nature 345, 175-176.

Clemens, D. L. (1996). Characterization of the Mycobacterium tuberculosis phagosome. Trends Microbiol 4, 113-118.

Deshpande, R. G., Khan, M. B., Bhat, D. A. \& Navalkar, R. G. (1997). Isolation of a contact-dependent haemolysin from $M y$ cobacterium tuberculosis. J Med Microbiol 46, 233-238.

Eiglmeier, K., Honore, N., Woods, S. A., Caudron, B. \& Cole, S. T. (1993). Use of an ordered cosmid library to deduce the genomic organization of Mycobacterium leprae. Mol Microbiol 7, 197-206.

Fischer, L. J., Quinn, F. D., White, E. H. \& King, C. H. (1996). Intracellular growth and cytotoxicity of Mycobacterium haemophilum in a human epithelial cell line (Hec-1-B). Infect Immun 64, 269-276.

Flynn, J. L., Goldstein, M. M., Triebold, K. J., Koller, B. \& Bloom, B. R. (1992). Major histocompatibility complex class I-restricted $\mathrm{T}$ cells are required for resistance to Mycobacterium tuberculosis infection. Proc Natl Acad Sci USA 89, 12013-12017.

ter Huurne, A. A., Muir, S., van Houten, M., van der Zeijst, B. A., Gaastra, W. \& Kusters, J. G. (1994). Characterization of three putative Serpulina byodysenteriae hemolysins. Microb Pathog 16, 269-282.

Hyatt, D. R. \& Joens, L. A. (1997). Analysis of the lytic activity of the Serpulina byodysenteriae hemolysin. Infect Immun $\mathbf{6 5}$, $4877-4879$.

Hyatt, D. R., ter Huurne, A. A., van der Zeijst, B. A. \& Joens, L. A. (1994). Reduced virulence of Serpulina hyodysenteriae hemolysinnegative mutants in pigs and their potential to protect pigs against challenge with a virulent strain. Infect Immun 62, 2244-2248.

Johansen, K. A., Gill, R. E. \& Vasin, M. L. (1996). Biochemical and molecular analysis of phospholipase $C$ and phospholipase D activity in mycobacteria. Infect Immun 64, 3259-3266.

King, C. H., Mundayoor, S., Crawford, J. T. \& Shinnick, T. M. (1993). Expression of contact-dependent cytolytic activity by Mycobacterium tuberculosis and isolation of the genomic locus that encodes the activity. Infect Immun 61, 2708-2712.

Leao, S. C., Rocha, C. L., Murillo, L. A., Parra, C. A. \& Patarroyo, M. E. (1995). A species-specific nucleotide sequence of $M y c o-$ bacterium tuberculosis encodes a protein that exhibits hemolytic activity when expressed in Escherichia coli. Infect Immun 63, $4301-4306$

McDonough, K. A., Kress, Y. \& Bloom, B. R. (1993). The interaction of Mycobacterium tuberculosis with macrophages: a study of phagolysosome fusion. Infect Agents Dis 2, 232-235.

Mangan, J. A., Sole, K. M., Mitchison, D. A. \& Butcher, P. D. (1997). An effective method of RNA extraction from bacteria refractory to disruption, including mycobacteria. Nucleic Acids Res 25, 675-676.
Moreira, A. L., Wang, J., Tsenova Berkova, L., Hellmann, W., Freedman, V. H. \& Kaplan, G. (1997). Sequestration of Mycobacterium tuberculosis in tight vacuoles in vivo in lung macrophages of mice infected by the respiratory route. Infect Immun 65, 305-308.

Muir, S., Koopman, M. B., Libby, S. J., Joens, L. A., Heffron, F. \& Kusters, J. G. (1992). Cloning and expression of a Serpula (Treponema) byodysenteriae hemolysin gene. Infect Immun 60, 529-535.

Porter, J. D. (1996). Mycobacteriosis and HIV infection: the new public health challenge. J Antimicrob Chemother 37, 113-120.

Rodrigues, L. C. \& Smith, P. G. (1990). Tuberculosis in developing countries and methods for its control. Trans $R$ Soc Trop Med Hyg 84, 739-744.

Sambrook, J., Fritsch, E. F. \& Maniatis, T. (1989). Molecular Cloning: a Laboratory Manual, 2nd edn. Cold Spring Harbor, NY: Cold Spring Harbor Laboratory.

Santos, A. R., De Miranda, A. B., Lima, L. M., Suffys, P. N. \& Degrave, W. M. (1992). Method for high yield preparation in large and small scale of nucleic acids from mycobacteria. $J$ Microbiol Methods 15, 83-94.

Smith, P. G. \& Moss, A. R. (1994). Epidemiology of tuberculosis. In Tuberculosis: Pathogenesis, Protection and Control, pp. 47-59. Edited by B. R. Bloom. Washington, DC: American Society for Microbiology.

Snapper, S. B., Melton, R. E., Mustafa, S., Kieser, T. \& Jacobs, W. R., Jr (1990). Isolation and characterization of efficient plasmid transformation mutants of Mycobacterium smegmatis. Mol Microbiol 4, 1911-1919.

Snider, D. E., Jr, Raviglione, M. \& Kochi, A. (1994). Global burden of tuberculosis. In Tuberculosis: Pathogenesis, Protection and Control, pp. 3-11. Edited by B. R. Bloom. Washington, DC: American Society for Microbiology.

Stover, C. K., de la Cruz, V. F., Fuerst, T. R. and 11 other authors (1991). New use of BCG for recombinant vaccines. Nature 351, $456-460$.

Thompson, J. D., Higgins, D. G. \& Gibson, T. J. (1994). CLUSTAL w : improving the sensitivity of progressive multiple sequence alignment through sequence weighting, position-specific gap penalties and weight matrix choice. Nucleic Acids Res 22, 4673-4680.

Turner, J. \& Dockrell, H. M. (1996). Stimulation of human peripheral blood mononuclear cells with live Mycobacterium bovis BCG activates cytolytic CD8 + T cells in vitro. Immunology 87, 339-342.

Udou, T. (1994). Extracellular hemolytic activity in rapidly growing mycobacteria. Can J Microbiol 40, 318-321.

Wren, B. W., Colby, S. M., Cubberley, R. R. \& Pallen, M. J. (1992). Degenerate PCR primers for the amplification of fragments from genes encoding response regulators from a range of pathogenic bacteria. FEMS Microbiol Lett 78, 287-291.

Yang, J. W., Dhamija, S. S. \& Schweingruber, M. E. (1991). Characterisation of the specific p-nitrophenylphosphatase gene and protein of Schizosaccharomyces pombe. Eur J Biochem 198, 493-497.

Received 11 November 1997; revised 12 January 1998; accepted 16 January 1998. 